\title{
ON LAND (WEALTH) DISTRIBUTION: A CULTURAL APPROACH TO JUSTICE IN INDONESIA
}

\author{
Suparjo $^{1}$
}

\begin{abstract}
This article re-examines the Indonesian land distribution policy in light of Pancasila, the five core values of the Indonesian constitution. Furthermore, the article also analyzes social problems in Indonesia from the legal and cultural point of view. Inspired by Javanese shadow puppet plays and Pancasila values, analysis shows that that land distribution policy in Indonesia does not support the goal of the country. The policy does not adhere to Pancasila values and the cultural values adopted by the Indonesian people. Hence I will try to give a recommendation for better regulation in land distribution. Evidences will be given to support the revision of land distribution policy in Indonesia by involving the academics through their researches and legal knowledge. This paper will also prove how doing so would resolve a lot of problems as poverty, unemployment matters, and social gaps; therefore social-economic justice can be promoted in accordance with the goals of the country.
\end{abstract}

Keywords: distribution, land, wealth

\section{Introduction}

This paper will take a perspective from the law and culture in South East Asia, particularly in Indonesia. ${ }^{2}$ The cultural approach that I will use to elaborate here is inspired from the shadow puppet plays, which is originally based on the epic stories from India. I will explain some Indonesia early historical phases at first, and then try to relate them with the issue of land distribution.

The problem of land (wealth) distribution begins with the issue of justice. To answer the issue, I will try to make use of some Javanese phrases often mentioned in local shadow puppet (wayang kulit) shows. Prior to the play, the shadow master (Ki Dalang) always gives a background story informing the reader about the social condition of the country. The countries depicted in the epic stories are always big by land area and rich in natural resources, such as the Astina Pura and Amarta Pura. The Ki Dalang also explains the characters of

1 Lecturer at Faculty of Law, University of Indonesia. Obtained Bachelor of Law (S.H.) from University of Indonesia, Master of Law (M.H.) from University of Indonesia. The author can be contacted at suparjo@ui.ac.id

${ }^{2}$ This paper is an essential part of my Ph.D (preliminary) research and was presented exclusively at International Conference on Law and Culture in South East Asia, Djokosoetono Research Center, Faculty of Law University of Indonesia, Depok, on July 13th, 2011. 
the leader in the story as well and how justice is delivered in the country. ${ }^{3}$

The society is always dependent on the feudal system, as told in either Ramayana or Bharatayudha epic. The king is described to be wise and highly devoted by his people, with his divine power as God's representative on Earth. $\mathrm{He}$ is described to be greatly consistent in protecting the people's rights. In short, the epic stressed the ideal figure ruling the imperium.

Nevertheless, this paper will discuss neither the nature of feudal nor feudal state. The primary focus will rely on the modern thoughts about state, people, and natural resources. In addition, I will also explain how such ideologies developed by notable political philosophers as libertarian, utilitarian, egalitarian, and communitarian may influence the politics of many countries around the world.

Finally, this paper will try to suggest how the philosophy of state and politics should be manifested in legal system, based on the idea to preserve and sustain justice to entire people. To be more specific, our discussion will focus on the land (wealth) distribution as the primary issue.

\section{A. Negoro panjang punjung, gemah ripah loh jinawi : Description on the Land and Prosperity of the Country}

Indonesia is known as the world sixteenth-largest country in the world in terms of land area. ${ }^{4}$ Therefore, it is called in Javanese language as "negoro panjang punjung". Its location lies along the equator. Consequently, the climate tends to be relatively even throughout the year. This leads to high level of ecological diversity and arability of the lands in almost every region.

Indonesia's natural resources abundance has also been well-identified since decades ago. In his book "Indonesia Accuses!" ("Indonesia Menggugat!") as his defense before the colonial court, ${ }^{5}$ the founding father Soekarno noted the fact that until 1927 the value of the exploited Indonesia natural resources contributed to the Netherlands was worth annually at least 1.5 billion Dutch guilder. ${ }^{6}$

Moreover, Indonesia wealth was also affirmed by two former Presidents of the United States of America as well. First, Harry S. Truman mentioned the regions by its natural resources : "South East Asia, especially Malaya and Indonesia, is the principal world source of natural rubber and tin; producer of petroleum and other strategic commodities."7

${ }^{3}$ My cultural approach is mostly excerpted from by well-known local website "Wayang Indonesia:Masterpiece of Oral and Intangible Heritage of Humanity" at URL= <http://wayang.wordpress. $\mathrm{com} /$. > where I myself registered as a member of community of wayang lovers.

${ }^{4}$ CIA, https://www.cia.gov/library/publications/the-world-factbook/rankorder/2147rank.html.

${ }^{5}$ Soekarno, Indonesia Menggugat : Pidato Pembelaan Bung Karno di Muka Hakim Kolonial. (Jakarta : SK Seno, 1956).

${ }^{6}$ It all was only by agricultural products in domination and not including the natural resources deposits in West Papua, coal in Kalimantan, oil and plantation in both Sumatra and Kalimantan, natural gas in Natuna, and so on.

${ }^{7}$ John Roosa, Pretext for Mass Murder : The September 30th Movement \& Suharto's Coup D'Etat in 
Second, Richard Nixon expressed his opinion about the country, which he described as "containing the region's richest hoard of natural resources" and "by far the greatest prize in the South East Asia." Both opinions from these American leaders have significance in this investigation, as mentioned by Kahin. This might be a potential reason of American interference to Indonesia through their foreign policies initiated since the 1950s. ${ }^{9}$

\section{B. Toto Titi Tentrem Karto Raharjo : Social Order and Social Welfare as Objectives}

The use of abundant natural resources in Indonesia should conform to the state ideology and socio-economic justice under the 1945 Constitution. Article 33 (2) stipulates that the land, the waters, and the natural resources within shall be under the control of the State. The general (public) welfare is the main concern here.

The social welfare of the entire people as a primary target was ever figured by Soekarno in his historical speech on June $1^{\text {st }}, 1945$ before the assembly of the Investigating Committee of Indonesia Independence Preparation (Badan Penyelidik Usaha Persiapan Kemerdekaan Indonesia) known as the moment of the Birth of Pancasila. He said :

"Principle number four, no I propose. Within three days I have not listened to the principle, namely the principle of welfare; the principle which says that there would be no poverty in the Independent Indonesia. I said : principally San Min Chu I was Mintsu, Min Chuan, Min Sheng : Nationalism, Democracy, Socialism. So the principle we should be is : Do we want the independent Indonesia, where the capitalists reigns, or where all people prosper, have enough to eat, enough clothing, live in prosperity, in the lap of our Mother of Earth who can provide sufficient food and clothing to them?"

It does reflect social welfare and order ("toto titi tentrem karto raharjo") idea.

Soekarno once more highlighted the social order and welfare as the main concern of the country, in his speech at the short moment to liberation of West Papua :

"Soon after 1 May 1963 Irian Jaya (West Papua) entered into the Republic of Indonesia, then will never happen more l'exploitation de l'homme par homme, and will become a society, Indonesian people with happy living. A society which will never happen as a crying mother, because she cannot breastfeed her own child. A intelligent society that will be formed by

\footnotetext{
Indonesia. (Madison : University of Wisconsin, 2006), 14.

${ }^{8}$ Richard Nixon, "Asia After Viet Nam," Foreign Affairs 46, No. 1 (October 1967) .

${ }^{9}$ See Audrey R. Kahin and George McT. Kahin, Subversion as Foreign Policy, The Secret Eisenhower and Dulles Debacle in Indonesia. (New York, The New Press, 1995).
} 
thousands milion of "insan kamil"10 people (manusia berbudi luhur, or virtue people) living on the land underneath the sky created by God". ${ }^{11}$

Luhur budi (moral virtue) of people is acquired from excellent education and adequate standard of living. Amartya Sen, a Nobel laureate in Economics (1998), introduced a nearly similar concept called "Human Capability", which is later developed to the Human Development Index (HDI). HDI has become the United Nations standard means of measuring country development worldwide. Development processes use and manage natural resources to satisfy human needs and improve people's quality of life. Note that those who hold these views may still range from the Marxist to neoclassical.

The key ideas of Sen's capability approach are "capability" and "functioning". Functionings are what Sen calls 'the various things a person may value being and doing. ${ }^{12}$ For example, being adequately nourished, being in good health, avoiding escapable morbidity, being happy, having self-respect, and taking part in the life of the community. ${ }^{13}$

To sum up, I conclude that both Sukarno and Sen show a similar view on human capability, despite their belonging to different era and fields of excellence.

\section{Economic as Sustaining Portrait of Injustice (Land as 'Bumi' under Indonesian Land Law Number 5 Year 1960 and Divergence)}

This analysis rests its argument upon American political interference to Indonesia on the second ultimate history phase. I have found at least 70s researches about it. The history has been ignored, in spite of its influential impacts to the national ideology and social-economic justice. From this point, I will elaborate the problem regarding land distributions by questioning justice related to the previous section above.

\section{A. Enthek alas enthek ngomah as the influence to philosophy and policy divergence}

This section will discuss the relation of Indonesia, precisely its natural resources, to international politics around 1950-1960. The Kennedy

${ }^{10}$ Jamil Sahliba, (1978), Kamus Filsafat, (Dar al-Kitab al-Lubnani),[Dictionary of Philosophy] Vol. I. The word 'insan' show on something that is specific to human meaning in terms of its nature, not physical. In the Arabic word referring to the nature of human beings who praised such as compassion, noble and others. Furthermore, the word man is used by the classical philosophers as $\neg$ says pointing her in the totality of human meaning that directly leads to human nature. The word man is also used to show the meaning of gathering all the potential of intellectual, spiritual and physical that in humans, such as life, animality,etc. then 'kamil', can also mean a figure of perfect, and is used to indicate the substance and nature perfectly, and it happens through the accumulation of a number of potential and completeness of such knowledge, and all the other compassionates kind. by writer.

${ }^{11}$ Excerpt from verbatim audio Sukarno Speech before Front Nasional 1963 and free translation

${ }^{12}$ Amartya Sen, Development as Freedom. (Oxford : Oxford University Press, 1999), 75.

${ }^{13}$ Amartya Sen, Inequality Reexamined. (Oxford : Oxford University Press, 1992), 39. 
administration seemed to have put a hidden agenda on the country behind their foreign aid policy due to the hoarded natural resources, strategic location astride lines of communication in the South West Pacific area, and the fact that it was destination to the U.S. commercial investments. Hence, Indonesia was seen as the key to the victory of the United States at that time, to influence the nonaligned countries during the Cold War. ${ }^{14}$

By late 1950s, Washington's approach towards Indonesia was marked by ambiguity. The Eisenhower administration's effort to undermine Sukarno's regime in 1958 through the support for Revolutionary Government of the Republic of Indonesia (Pemerintahan Revolusioner Republik Indonesia or P.R.R.I.) rebels in Indonesia was the most notable action in that period. This started Indonesian's suspicion of the United States ultimate intentions. It should be noted that in 1959 the United States continued to offer a covert backing for the remnants of the P.R.R.I. Though later the Eisenhower administration turned to Indonesia's side (by providing limited amount of military assistance to the army forces following the failed rebellion) in the effort to encourage anti-communism spirit within upper echelons of the army, Jakarta was still under restraint of the United States. Compared to the aid offered by the Communist Bloc, the United States' military assistance seemed meager. ${ }^{15}$

Moreover, from Jones's point of view, in American's opinion Sukarno seemed to enjoy a generally low reputation in the media due to the increasingly personalized nature of his rule, his good relationship with the Indonesia Communist Party (Partai Komunis Indonesia or P.K.I.). and what were seen as his dubious personal moral value. Dulles, for instance, could never quite seem to overcome his distaste for the Indonesian President's fondness for a variety of female companions. ${ }^{16}$

Jones' analysis seems so plausible since nothing is proven right and his book only represented his judgments. Blum confessed that the dirty job done by CIA uncivilized operation. In his book Blum assumes that the success of that dirty operation by justifying any means inspired CIA officers in Washington to carry the theme one step further.

To lose the president credibility, some photographs of a couple resembling Sukarno and his Russian female friend engaged in "his favorite activity" was made up. After investigating such films, it failed to reveal the true identity of the bald, dark-skinned man and the beautiful Russian blonde. The CIA later undertook production of "the very films which the Soviets were blackmailing Sukarno". The Agency developed a full-face mask of the Indonesian leader which was to be sent to Los Angeles, where the police were to pay some porn actors to

${ }^{14}$ See Steven I. Levine, "Breakthrough to the East : Soviet Asian Policy in the 1950s", in The Great Powers in East Asia, 1953-1960, ed. Warren I. Cohen and Akira Iriye (New York : 1990), 304; Justus M. van der Kroef, "Soviet and Chinese Influence in Indonesia", in Soviet and Chinese Influence in the Third World (London : 1975), 54-5.

${ }^{15}$ Audrey R. Kahin and George McT. Kahin, Subversion as Foreign Policy: The Secret Eisenhower and Dulles Debacle in Indonesia. (New York: The New Press, 1995), 77.

${ }^{16}$ Matthew Jones, Conflict and Confrontation in South East Asia, 1961-1965. Britain, the United States and the Creation of Malaysia. (New York : Cambridge University Press, 2002), 32. 
wear it during his big scene. This project resulted in at least some photographs, although they were apparently never used..$^{17}$

The conspiracy, as Blum said, was initiated not by unintelligent individuals, in spite of their superior education and well-developed society. War and pornography have become the way to get over their lack of confidence. A Machiavellian thought!

It has been confirmed that CIA has involved (as the "puppet master") in the Indonesian 1 October 1965 coup attempt. ${ }^{18}$ The political intrigue then resulted in as follows:

a. Indonesia change of leader and political configuration, reflecting the country as a state under control, as the wayang di tangan Ki Dalang (puppet in the master hands).

b. The "puppet master" has a hidden agenda to take most advantages of such Indonesia's natural resources as cooper, gold, oil, timber, and so on behind their foreign aid offer.

c. Being unable to pay their debt later, this developing country is forced to acquiesce to political pressure from the United States. Consequently, the local economy is easily dominated. ${ }^{19}$

d. The miscarriage of justice, ideological shift, and violation of the law.

e. Economic and political instability

f. Corruption, poverty, and the gap between the rich and the poor as a trigger for the political instability. ${ }^{20}$

Enthek alas enthek ngomah is a Javanese idiom which says that all sufferings, pain, and misery (point a to f above) resulted from nothing else but the bloodbath of thousands of Indonesia civilians.

The land distribution policy regulated in the Law Number 5 Year 1960 and Law Number 56 Year 1960 is perceived to be not effective in protecting the local economy. Many reports indicate that the policy does not conform to the public interest.

${ }^{17}$ William Blum, Killing Hope U.S. Military and CIA Interventions Since World War II - Part I. (London : Zed Books Ltd., 2003).

${ }^{18}$ Fealy Greg, The Release of Indonesia's Political Prisoners: Domestic Versus Foreign Policy, 19751979. (Clayton: Monash Asia Institute, 1995), noted that in addition to those killed, 600,000-750,000 people were also imprisoned, ranging from one to thirty years, as quoted by Katherine E. McGregor, "The Indonesian Killings of 1965-1966," Online Encyclopedia of Mass Violence, accessed http://www. massviolence.org/PdfVersion?id_article=343.

${ }^{19}$ See John Perkins, Confession of Economic Hit Man. (San Fransisco : Berrett-Koehler Publishers, Inc., 2004); also John Perkins, The Secret History of the American Empire : Economic Hit Men, Jackals, and the Truth about Global Corruption, (New York : Penguin Group).

${ }^{20}$ Steven Hiatt, A Game As Old As Empire : The Secret World of Economic Hit Men and the Web of Global Corruption. (San Fransisco : Berrett-Koehler Publishers, Inc.). 
The 2003 Indonesian agricultural census shows that the total number of poor farmers (working less than 0.5 hectare of land) reached 13.7 million households; increasing by $26.85 \%$ compared to 1993 . They all live below the poverty line. Out of $16.6 \%$ Indonesian people classified into the underprivileged group, $60 \%$ of them are farmers. ${ }^{21}$

According to the data released by National Land Agency in March 2007, the land distribution policy has not succeeded in promoting the general welfare. The table below shows some current national social problems:

\begin{tabular}{|l|l|l|l|}
\hline NO. & \multicolumn{1}{|c|}{ PROBLEM } & \multicolumn{1}{|c|}{ INDICATOR } & \multicolumn{1}{|c|}{ NOTE } \\
\hline 1. & Poverty & $\begin{array}{l}\text { 39.05 million people slipped into } \\
\text { poverty }\end{array}$ & $\begin{array}{l}\text { 17.75\% of } \\
\text { population }\end{array}$ \\
\hline 2. & $\begin{array}{l}\text { Unemployment } \\
\text { (Scattered in } \\
\text { rural and urban } \\
\text { areas) }\end{array}$ & $\begin{array}{l}\text { - Open-employed 11 millions } \\
\text { - Disguised-employed: } \\
\text { millions }\end{array}$ & $\begin{array}{l}\text { 10.45\% of } \\
\text { population 28.16\% } \\
\text { of population }\end{array}$ \\
\hline 3. & Social Gaps & $\begin{array}{l}\text { - The majority poor households } \\
\text { live in rural areas } \\
\bullet \text { Small-scale land cultivation }\end{array}$ & $\begin{array}{l}\text { Small farmers } \\
\text { (less than 0,5 ha) } \\
\text { amounting to 54 \% }\end{array}$ \\
\hline 4. & $\begin{array}{l}\text { Land Dispute } \\
\text { and Conflicts }\end{array}$ & $\begin{array}{l}\text { Numerous dispute and land } \\
\text { conflict, land is not optimally used. }\end{array}$ & \\
\hline
\end{tabular}

\section{B. Sudiro jayadiningrat lebur dening pangastuti : A Critique Towards Capitalist Economy System and Excess of Justice}

Departing from the wickedness occurred and remains up to now, there arises a question of justice. The ideological shift, the violation of the law, and corrupt government are resulted from the mass killing under political turbulence in the 1960s. They depict the evil Machiavellian way known in Javanese culture as the "Sudiro jayadiningrat".

This kind of wicked behavior is well explained by Wahib from UIN Sunan Kalijaga, Yogyakarta in his research on the "Mystical Doctrine of Dewaruci Tale". He concluded that Dewaruci Tale literary mysticism is that the overall value of mystical, despite such Dewaruci Tale is a work of art that contains the value of ultimo art . It's just more highlighted mystical value. This is clearly evident from the moral values of the story. The teaching of Dewaruci tale tells us that the morality of human itself that determines if he/she can bring the magnificence, peace, and world preservation into reality; it is "memayu hayuning" or "sudiro jayadiningrat".

The Bharatayudha episode in the epic story is an appropriate example of how war is seen as a final, unavoidable solution to end a prolonged conflict, after the failure of Pandawa convicting their brothers, Kurawa family.

${ }^{21}$ Ukay Karyadi, “Politik Pertanian untuk Kesejahteraan Petani”, accessed 18 December, 2006, sinarharapan.co.id/berita/0602/09/opi02.html, as citated by Suparjo, "The Urgency of Amending Indonesia's Basic Agrarian Law" (paper presented at Washington School of Law, Seattle, United States, February 27-28, 2007). 
Amartya Sen in his book The Idea of Justice explains briefly the conflict between Krishna and Arjuna prior to the Bharatayudha war :

"Or consider a different kind of example. In the Indian epic Mahabharata, in the particular part of it called Bhagavad-Gita (or Gita, for short), on the eve of the battle that is the central episode of the epic, the invincible warrior, Arjuna, expresses his profound doubts about leading the fight which will result in so much killing. He is told by his adviser, Krishna, that he, Arjuna, must give priority to his duty, that is, to fight, irrespective of the consequences. That famous debate is often interpreted as one about deontology versus consequentialism, with Krishna, the deontologist, urging Arjuna to do his duty, while Arjuna, the alleged consequentialist, worries about the terrible consequences of the war." 22

The inner conflict of Arjuna above deeply concerns about humanism. At first he refused to kill the Kurawas because they are his brothers. Arjuna's moral conscience is beyond all materialism thoughts. Consequentialism, as expressed in Krishna's argument, allows the successor to gain the right over property. However, the deontological decision of Arjuna's rests the argument on features of act more than just materialism. This is the most critical value from the cultural view to point out how justice must be seen to be done.

\section{Modern concept as solution (Legal conscience and Reform)}

Following our discussion on cultural values and reality, legal scholar should offer solutions to the problem rather than just criticizing. Legal education is taught to give a recommendation to legal reform process. Researches and education program should be in accordance with the national legal reform agenda. The involvement of the past and present generations will raise their legal consciousness from both sides. Alert them about their future in better. Approach can be initiated if the process is consistent. All ideas are by considering reality in legal and more social-economic justice. The past history of Indonesia's authoritarian regime and current social issues should not be an obstacle but an initial step to move ahead.

Pancasila should be set as the supreme value manifested in the legal reform process in accordance with its role as the stufenbau; applied effectively up to present. It will be a brighten idea in scholars mind and civilized way that also considers holistic approach by smart thinking and further decision taken. This approach is straightly different to war and Machiavellian ways at the sustaining in Indonesia experiences.

\section{Pancasila manifestation as legal scholar challenge: forgotten or silliness?}

About Pancasila in three fundamental changes of state and government on my idea is somewhat like 'used goods' that only being needed in emergency

${ }^{22}$ Amartya Sen, The Idea of Justice. (Cambridge, Massachusetts, The Belknap Press of Harvard University Press, 2009), 23-24. 
case. It will forget in certain circumstance that becomes pattern of advantage takers doing. Let me give arguments below:

Firstly, by it birth reflected by political pressure in mid of 1945 when World War II progress seemed would promise independence. Then founding fathers prepare all needs to built new state. It's looked any necessity demand on philosophy grondslag (state ideology, way of life the nation). Then by politic and national defense turbulences Pancasila was put in distance war by state instability. It is shown by liberal democracy in 1950 Constitution was ever applied until the last 1950s before Soekarno Decreed as know "Presidential Decree of 5 July 1959".

Secondly, post bleeding-revolution 1965 under Suharto regime again Pancasila treated as used good. Suharto is as puppet that must play his master game. Pancasila as united ideology then being reduced as authoritarian tools to face any political-opposition by labeling as well "ANTI-PANCASILA" and "PKIfollowers" effective done during Suharto presidential era. Pancasila have been used nota as valuable goods kind, but used goods in committed-repetition about abuse.

Thirdly, by nightmares during Suharto regime that was 'used' Pancasila to create massive terror and hyper action through his politic enemies then since reformation moment Pancasila also have been treated as used good. By euphoria happen upon politic and legal thinkers have spread over in many aspects such as politic, economic, social influIt is all by one same spirit that something cannot be done at prior time can be done now and by leave intellectual approach, mostly in legal thought. Pragmatism and liberalization occurs and continues in recent time. Pancasila still exist but in this recent period like no more useful goods and ignored as well.

Nonetheless, the problem is that legal scholars are not used to implement Pancasila values into legal research and legal reform process. Pancasila is only percepted as a abstract concept. In addition, the legal education system does not give adequate support to manifest these dynamic values in their research. Have Pancasila been manifested in all of law faculty learning subject? Also can be commenced by critical evaluation to each subject concerning those logiccorrelations to the Pancasila grand ideas as an ought to.

Pancasila character itself accepted commonly as dynamic ideology that also have universal values by whatever legal trends and tends of change should be explained by it. Let me take position here that learning Pancasila by legal education and research will promise better order of justice and peaceful social life in many aspects. It will be a necessity by universal dogma that teaches us regarding good law structure and logic in no contradiction and harmony in entire legal system. It also highlighted here as best alternative than Bharatayudha had ever offered. Perhaps many legal scholars forgot that under Pancasila that teaches that wickedness will always be beaten by goodness as a moral truthful. 


\section{Reconceptualization of Justice: Human-Land Benefit as Economic Sustaining}

Memayu Hayuning Bawono Ambrasto durangkoro: a local-universal wisdom "human virtue as integrated element of universe"

The "good and evil" philosophy itself has been understood since the Ancient Greek period. But later we will see how contrast the reality to what it ought be through legal, philosophy, and political sides.

The human and humanity have become the main attention of legal, philosophy, and political studies. All stream of schools embark on the same point, then develop differently. Justice is definitely the aim of every country around the world. It should be seen as the root of human virtue, the guide to deal with all problems. It is similar to Arjuna's deontological view; should anyone be happy to see other people suffer? It is the root of all equality, not the durangkoro behavior.

\section{A. Social justice as universal concept and needs: difference in absolute by political thoughts?}

Land (wealth) distribution is adapted from Hukum Adat (Adat Law) principle related to human and land benefit. Hukum Adat teaches the principle of harmony as well as interdependency between human being and land. Human can get benefit from the land, for instance farm, plantation, mining, and forestry products. Land also gets benefit from human by it fertile because not in long time must supply plants, forest ecology needs. Mine reclamation will restore the land to its natural condition. Fertile soil and better, new ecological harmony.

Above divergences in political thought and legal system of course ought to be grasped by the harmony in human-land benefits relation as mutualism symbiosis, by each other needs as a mirror. Every state has freedom to choice their mainstream political and legal system in utilitarian, libertarian, egalitarian by self experience. Then if it manifestation will be in chauvinist or hegemony power. It forgets that a state won't stay alone to fulfill their people needs and in wrong choice then by practices of survival for the fittest-principle as Darwinian and Spencerinian will bring human behavior to their Machiavellian character.

That is human evil-nature, so that why philosophers taught us by their wisdom thought by rethinking about humanity need in broader as we call justice, social justice, economic justice, political justice.

Excerpt about the truth, more lessons from Bharatayudha. The plot of story is at the close end of the war after Bima can beat Suyudana. On the looser position Suyudana still has idea to beat Bima morality as the next winner of war. Bima almost lost his virtue when listen that Pandawa family as well himself become unlucky one. Suyudana means it in contrast by his happiness, richness, and power during his life to the painful experience in Pandawa life's that enough suffered, poverty. Even by victory in hands but pandawa will find the destroyed Kingdom of Astina Pura. Then Suyudana closing word is that Pandawa have win the war but still lose by all valueless property and everything are rested in post 
war. Is it true as a truth? This question shakes Bima virtue-personality at the moment of morality glory.

Those situations are almost worked, but then great moral advice to Bima come from Kreshna about the truth characters: Firstly, the truth in the lowest level is the truth under individual thought and not absolute true for else personal (as individual truth) ; then in the second layer as higher, is about truth that become truth of group of society (as in-group truth, not as absolute for out-group members); thirdly, the ultimate truth that reflecting warrior-virtue conduct (lakuning satriyo utomo) and being accepted entire human being as well as universal dogma (as prime of truth).

Under those layers of truth what was Suyudana said is judged as truth, but not as universal truth or just individual (or his family) exclusive truth. Isn't it also linear to recent our discussion here about Indonesia experiences as victim?

\section{B. Greedy-expansive, environment-destructive through land exploitation model cannot save the earth and entire peoples}

Manifestation or in thought discourse that divergence concerning human-land benefits relation as character materialistic-greedy in everywhere include Indonesia will have destructive impacts through ecological, social, and economical. Moral deontology as Arjuna must be a mirror and inspires legal scholar and politician around the world to against destructive-greedy. Moral dogma must inspire far into politic and legal system then further be pursued by consistent law enforcement to maintain justice entire human-land benefits relation.

Memayu hayuning bawono ambrasto durangko : Against the Machiavellian ways to save the entire earth and promoting the harmony on the universe, as quoted by Gnaeus Domitius Annius Ulpianus "Honeste vivere, alterum non laedere, suum cuique tribuere".

Ironic situation as disaster of justice and humanity is while the income of PT FI twice increased as well seen in 2005, up to 4 times the GDP of Papua province. Human Development Index (HDI) Papua ranks 29 of 33 provinces. HDI value is expressed with high rates of maternal and infant mortality due to malnutrition. Worse still by "rests of poverty" in which are in the mining concession area of PT FI rises above 35\%. Becomes very ironic while salary and benefits of two CEO of PT FI (James Moffett and Richard Aderson) reached the U.S. \$ 207.3 million, average income of the population of Papua is less than U.S. $\$ 240$ per year. Agency of Finance Auditor (BPK) audit results in 2005 that the management of non-tax revenues at the Department of Energy and PT FI for fiscal year 2004/2005 shows that Indonesia has not got optimal income from mining contract with PT FI. Surprisingly up to now no any significant action undertaken by the government against PT Freeport. ${ }^{23}$

${ }^{23}$ Those details are reported on the JATAM (Network of Mining Advocation), accessed 4 July 2011, http://www.jatam.org/content/view/37/3/. 
Let us put that injustice to Arjuna deontology; or we can invite Amartya Sen to take this problem under his excelent human capability works and we willl get in what answer being, if still cannot scholarly reading and making clearconsistence analysis about memayu hayuning bawono ambrasto durangkoro.

It should be taken beyond opponents of moral dilemmas noted that the problem of dirty hands represents both a challenge and an opportunity. The challenge is to show how conflicts between general obligations and rolerelated obligations, and those among the various role-related obligations, can be resolved in a principled way. The opportunity for theories that purport to have the resources to eliminate dilemmas-such as Kantianism, utilitarianism, and intuitionism - is to show how the many moralities under which people are governed are related. ${ }^{24}$

As the closing words of the puppet show, the Ki Dalang always said "Memayu hayuning bawono ambrasto durangkoro". It reminds us of the victory of goodness over wickedness, thus the moral dilemma is simply solved.

Ki Dalang and Ulpianus has the same moral message : "To live honestly, not to harm the others, to give to each his own".

Ulpianus say in preliminary (as primo-prevention) phase, but "Memayu hayuning bawono ambrasto durangkoro" are contained more anticipation in human-land benefits (as ultimo-anticipation). It means that maintaining, proctecting, and preserving the universe are the attitude of life of Javanese ancestors. They greatly appreciate the nature as it has given many advantages for us. Therefore, it is appropriate that we protect it. Here the law of harmony applies; if we keep the nature, then the nature will also keep us back in return; but if we ruin it then the wrath of nature is upon us.

In the perspective of state and people life and justice disaster are clear as well shown in many regions that rich by natural resources deposits who living in poverty. Is it God quiet blessing to the disasters actor?

\section{Conclusion}

From the explanation above, I conclude that land distribution policy in Indonesia have not supported the goal of country. By involving the academics through their researches and legal education, the policy should be reformed in accordance to Pancasila values. By doing so, such problems as poverty, unemployment matters, and social gaps will be resolved and social-economic justice shall be promoted high in the country.

${ }^{24}$ See in Larry Alexander and Michael Moore, "Deontological Ethics", The Stanford Encyclopedia of Philosophy, (Fall 2008), http://plato.stanford.edu/archives/fall2008/entries/ethics-deontological, and Terrace McConnell, “Moral Dilemmas," The Stanford Encyclopedia of Philosophy, (Summer 2010), http:// plato.stanford.edu/archives/sum2010/entries/moral-dilemmas/ 


\section{Bibliography}

\section{Books}

Blum, William. (2003). Killing Hope U.S. Military and CIA Interventions Since World War II - Part I. London : Zed Books Ltd.

Greg, Fealy. (1995) The Release of Indonesia's Political Prisoners : Domestic versus Foreign Policy. Clayton : Monash Asia Institute.

Hiatt, Steven. (2007). A Game As Old As Empire : The Secret World of Economic Hit Men and the Web of Global Corruption. San Fransisco : Berrett-Koehler Publishers, Inc.

Kahin, Audrey R. \& George McT. Kahin. (1995). Subversion as Foreign Policy : The Secret Eisenhower and Dulles Debacle in Indonesia. New York : The New Press.

Jones, Matthew. (2002). Conflict and Confrontation in South East Asia, 19611965. Britain, the United States, and the Creation of Malaysia. New York : Cambridge University Press.

Kroef, Justus M. van der (1975) Soviet and Chinese Influence in Indonesia. In : Rubinstein, Alvin Z. (eds). Soviet and Chinese Influence in the Third World. London : Praeger Publishers.

Levine, Steven I. (1990) Breakthrough to the East : Soviet Asian Policy in the 1950s. In : Cohen, Waren I. and Iriye, Akira. (eds). The Great Powers in East Asia. New York.

Perkins, John. (2004). Confession of Economic Hitman. San Fransisco : BerrettKoehler Publishers, Inc.

Perkins, John. (2007). The Secret History of the American Empire : Economic Hit Men, Jackals, and The Truth About Global Corruption. New York : Penguin Group.

Roosa, John. (2006). Pretext for Mass Murder : The September 30th Movement and Suharto's Coup d'Etat in Indonesia. Madison : University of Wisconsin Press.

Sen, Amartya. (2009). The Idea of Justice. Cambridge, Massachusetts : The Belknap Press of Harvard University Press.

Sen, Amartya. (1992). Inequality Reexamined. Oxford : Oxford University Press.

Sen, Amartya. (1999). Development as Freedom. Oxford : Oxford University Press.

Soekarno. (1956) Indonesia Menggugat : Pidato Pembelaan Bung Karno di Muka Hakim Kolonial. 2nd ed. Jakarta : SK Seno.

\section{Journal}

Nixon, Richard M. (1967). Asia After Viet Nam. Foreign Affairs. 46 (1). 


\section{Digital References}

CIA [Online] Available from https://www.cia.gov/library/publications/theworld- factbook/rankorder/2147rank.htm.

JATAM [Online] Available from ://www.jatam.org/content/view/37/3/. [Accessed : 4 July 2011].

Larry, Alexander \& Michael Moore. (2008) Deontological Ethics. [Online] The Stanford Encyclopedia of Philosophy. Available from http://plato. stanford.edu/archives/fall2008/entries/ethics- deontological/>.

McConnell, Terrance. (2010) Moral Dilemmas. [Online] The Stanford Encyclopedia of Philosophy. Available from http://plato.stanford.edu/ archives/sum2010/entries/moral-dilemmas/.

McGregor, Katherine E. (2009) The Indonesian Killings of 1965-1966. [Online] Online Encyclopedia of Mass Violence. Available from : http://www. massviolence.org/PdfVersion?id_article=343.

\section{Others}

Suparjo. (2007) The Urgency of Amending Indonesia's Basic Agrarian Law. Washington School of Law. 27-28 February 2007. 